\title{
Healthy Education in The Middle of Pandemi Covid-19 Through the Use of Social Media
}

\author{
Fitri Fatonah, Sugiyanto \\ Univsersitas Sebelas Maret \\ fitrifatonah@student.uns.ac.id
}

\section{Article History}

accepted 31/08/2020

approved 22/09/2020

published 28/10/2020

\begin{abstract}
Strategic and rapid efforts are needed to overcome the spread of Covid-19, one of them is by counseling through social media in order that scientific information is provided. The existence of so called Social Abdication Program of UNS in the form of Field Work Lecture addresses this issue, takes a theme "Education on the Exercise of Clean and Healthy Behavior (PHBS) and the Use of Medicines Provision in the Context of Preventing Covid-19 in RT 01 RW 01 Klegenwonosari Village, Klirong, Kebumen". The program uses social media (online) due to its need to maintaining physical distancing. However it also uses direct face-to-face activities on program socialization. The results of this community service activity show that: 1) there is an public awareness about facts about Covid-19,2) the application of PHBS and health tips, and understanding DAGUSIBU. Through quiz myths and fact, wider community can test their understanding of Covid-19 issues.
\end{abstract}

Keywords: Covid-19, Community Education, PHBS, DAGUSIBU

\begin{abstract}
Abstrak
Perlu upaya yang strategis dan cepat yang dilakukan di lingkungan sekitar untuk mengatasi penyebaran Covid-19, salah satunya dengan melakukan penyuluhan melalui media sosial untuk dapat memberikan informasi ilmiah. Program kegiatan pengabdian UNS dalam bentuk Kuliah Kerja Nyata ini dilaksanakan dengan tema "Edukasi Penerapan Perilaku Hidup Bersih dan Sehat (PHBS) serta Penggunaan Sediaan Obat Dalam Rangka Pencegahan Covid-19 kepada masyarakat RT 01 RW 01 Desa Klegenwonosari, Klirong, Kebumen". Metode pelaksanaannya menggunakan media sosial (daring) sebagai komunikasi utama strategi edukasi hidup sehat kepada masyarakat karena perlunya mematuhi menjaga jarak fisik tetapi hubungan sosial masih bisa dilakukan secara daring, selain itu itu juga menggunakan kegiatan tatap muka langsung pada sosialisasi program. Hasil kegiatan pengabdian ini menunjukkan: 1) pemahaman dan kesadaran masyarakat tentang fakta seputar Covid-19, 2) diterapkannya PHBS serta tips kesehatan, serta dipahaminya DAGUSIBU (Dapatkan, Gunakan, Simpan, Buang) obat. Melalui quiz mitos dan fakta, masyarakat luas dapat menguji pemahamannya seputar isu-isu Covid-19.
\end{abstract}

Kata kunci: Covid-19, Edukasi Masyarakat, PHBS, DAGUSIBU

Social, Humanities, and Education Studies (SHEs): Conference Series p-ISSN 2620-9284 https://jurnal.uns.ac.id/shes

e-ISSN 2620-9292 


\section{PENDAHULUAN}

Covid-19 merupakan penyakit infeksi oleh virus SARS CoV-2 yang mulai ditemukan pada akhir 2019 lalu. Gejala umumnya yaitu gangguan saluran pernafasan akut baik ringan maupun berat yang meliputi demam, batuk, sesak nafas, kelelahan, pilek, nyeri tenggorokan dan diare (WHO, 2020). Pandemi Covid-19 ini sangat menggemparkan dunia dan menimbulkan keresahan dari seluruh lapisan masyarakat. Hingga kini kasus positif Covid-19 di Indonesia masih terus bertambah setiap harinya.

Pengetahuan dan pemahaman yang ilmiah, akurat dan dapat dipercaya akan dapat membantu masyarakat untuk mudah melaksanakan himbuan dan arahan pemerintah guna menekan penyebaran Covid-19 (Sulaeman dan Supriadi, 2020). Meskipun WHO, Centers for Disease Control and Prevention (CDC) maupun Kementrian Kesehatan RI telah mengeluarkan banyak informasi-informasi aktual dan panduan-panduan terkait Covid-19, tetapi banyak masyarakat belum memahami secara benar (Karo, 2020). Minimnya pengetahuan dan pemahaman penduduk mengenai informasi yang valid tentang agen virus Corona dapat menimbulkan dampak sosial yang besar (Kurniawati dkk., 2020). Upaya cepat yang dapat dilakukan di lingkungan sekitar untuk mengatasi masalah tersebut adalah dengan melakukan berbagai kegiatan seperti penyuluhan untuk dapat memberikan data dan informasi yang ilmiah. Media sosial dapat dimanfaatkan secara cepat ntuk kepentingan penerima edukasi dan menjadi alat bagi konselor dalam menciptakan intervensi (Giota \& Kleftaras, 2014).

Media sosial telah menjadi salah satu media untuk edukasi, dimulai dari banyaknya informasi dan peluang terjadinya interaksi serta arahan untuk menuju pengembangan informasi ke dalam tautan lain (Kaya dkk., 2016). Hal tersebut menandakan bahwa selain dimanfaatkan sebagai media hiburan, media sosial dapat dijadikan sebagai alternatif sumber informasi, interaksi komunikasi terkait tanya jawab untuk pertanyaan keseharian termasuk info dan pertanyaan tentang Covid-19. Karena pembatasan jarak fisik yang ketat, orang sangat bergantung pada jaringan sosial digital global seperti Facebook atau Twitter, untuk memfasilitasi interaksi manusia dan berbagi informasi tentang virus (Limaye, dkk., 2020).

Media sosial memiliki kapasitas untuk menjangkau dan mempengaruhi jutaan orang Indonesia secara bersamaan. Kekuatan media yang paling jelas terletak pada jumlah individu yang dapat mereka jangkau. Media sosial dapat memengaruhi perilaku individu dan nilai-nilai komunitas yang turut mendukung lingkungan dan individu sehingga diperlukan untuk mempertahankan kebiasaan atas perubahan perilaku untuk sadar kesehatan. Selain itu, ketika pola pemberian layanan kesehatan terus berubah, media dapat memberikan informasi berharga kepada masyarakat tentang opsi dan sudut pandang lain. (Sampurno dkk., 2020). Komunikasi secara daring dalam hal ini menggunakan media sosial merupakan strategi promosi kesehatan yang dirancang dalam era pandemi Covid-19 untuk membentuk masyarakat yang melaksanakan perilaku hidup bersih dan sehat. Penelitian menunjukkan hasil kesadaran yang berkembang dalam anggota komunitas-komunitas media sosial untuk mengumpulkan informasi, mengeksplorasi pilihan, dan berbagi pengalaman (Thielst, 2011).

Media penyiaran dan banyak platform media cetak memiliki peraturan dalam menyebarkan informasi tetapi media sosial sebagian besar tidak diatur. Oleh karena itu, media sosial dapat terus berlanjut menyediakan mekanisme distribusi informasi medis yang salah di seluruh dunia (Allington dkk., 2020). Hasil penelitian menjelaskan alasan masih banyak orang yang percaya dan berbagi informasi yang salah terkait COVID-19 melalui media sosial. Diperlukan upaya meningkatkan kualitas informasi yang dibagikan secara online oleh masyarakat umum melalui intervensi agar dapat mencegah informasi yang tidak valid mengenai Covid-19 (Pennycook dkk., 2020). 
Kegiatan pengabdian masyarakat Universitas Sebelas Maret (UNS) yang dilaksanakan dalam bentuk Kuliah Kerja Nyata kali ini bermaksud memberikan intervensi edukasi dengan megambil tema "Edukasi Penerapan Perilaku Hidup Bersih dan Sehat (PHBS) serta Penggunaan Sediaan Obat Dalam Rangka Pencegahan Covid-19 untuk memberikan pengetahuan kepada masyarakat RT 01 RW 01 Desa Klegenwonosari, Klirong Kebumen". Penggunaan sediaan obat yang juga menjadi tema dalam kegiatan ini bermanfaat untuk mengedukasi masyarakat mengenai penggunaan obat secara umum maupun penggunaan vitamin dan suplemen untuk mendukung daya tahan tubuh di era pandemi ini. Kegiatan ini utamanya didukung oleh media sosial sebagai strategi edukasi hidup sehat kepada masyarakat karena perlunya mematuhi menjaga jarak fisik tetapi hubungan sosial masih bisa dilakukan secara daring. Edukasi yang dilakukan pada kegiatan ini menggunakan sumber resmi yang terpercaya sebagai bentuk pencegahan terhadap maraknya hoax yang dapat berpotensi meresahkan masyarakat.

\section{METODE}

Kegiatan KKN ini dilaksanakan selama 6 minggu, dari tanggal 15 Mei - 30 Juni 2020, berlokasi di RT01/RW01 Klegenwonosari, Klirong, Kebumen, Jawa Tengah. Metode utama yang digunakan adalah dengan media daring karena di masyarakat sedang terjadi pandemi Covid-19. Namun ada satu kegiatan yang dilaksanakan dengan tatp muka langsung namun dengan memperhatikan protokol kesehatan. Kegiatan yang dilakukan dengan media daring adalah:

- Program 1 : Edukasi fakta seputar Covid-19 dan seputar penggunaan obat;

- Program 2 : Video edukasi penerapan PHBS dan cara dapatkan, gunakan, simpan, dan buang obat dengan benar (DAGUSIBU);

- Program 3 : Podcast edukasi Adaptasi Kebiasaan Baru dan Seputar Penggunaan Obat;

- Program 5 : Infografis penyebaran kasus Covid-19 di Kabupaten Kebumen dan Nasional.

Sedangkan program kegiatan yang dilaksanakan secara langsung terjun di masyarakat adalah:

- Program 4 : Penempelan poster edukasi dan sosialisasi menggunakan leafleat

- Selain itu untuk melihat keberhasilan kegiatan ini dilakukan evaluasi melalui Quiz Mitos dan Fakta Seputar Covid-19 dan kuisioner Evaluasi Grup WAG PKK RW 01

Semua program kecuali program 4 dilaksanakan secara daring dengan memanfaatkan sosial media yaitu Instagram dengan akun @kepoincovid dan WAG PKK RW 01 yang beranggotakan ibu-ibu PKK RW 01 Desa Klegenwonosari. Hal ini dikarenakan peran ibu-ibu dalam rumah sangat dominan, sehingga dengan memberikan sosialisasi yang baik pada ibu-ibu diharapkan dapat lebih mengontrol semua anggota keluarga. Program 4 juga dilaksanakan dengan jaga jarak fisik yaitu dengan penempelan poster di lingkungan sekitar dan door to door melakukan sosialisasi menggunakan leafleat. 


\section{HASIL DAN PEMBAHASAN}

\subsection{Hasil Kegiatan}

Segala program yang telah dilakukan ini mendapatkan respon yang positif dari masyarakat khususnya anggota PKK RW 01 dan masyarakat pengikut instagram. Hasil dari pengabdian ini memberikan pemahaman dan kemampuan kepada masyarakat mengenai Fakta Seputar Covid19, Penerapan PHBS serta tips kesehatan dalam rangka menghadapi Covid-19, serta DAGUSIBU (Dapatkan, Gunakan, Simpan, Buang) Obat dengan Benar. Melalui quiz mitos dan fakta melalui akun instagram juga masyarakat luas dapat menguji pemahamannya seputar isuisu Covid-19 serta mendapatkan pengetahuan fakta melalui penjelasan quiz yang dibagikan.

Berikut ini media sosial yang dimanfaatkan dalam pemberian edukasi kepada ibu-ibu PKK RW 01 Desa Klegenwonosari, Klirong, Kebumen. Kegiatan berjalan dengan lancar berkat antusiasme partisipan. Ibu-ibu PKK dapat juga sebagai pemberi informasi dan penulis dapat memastikan kebenaran dari informasi-informasi yang dibagikan.
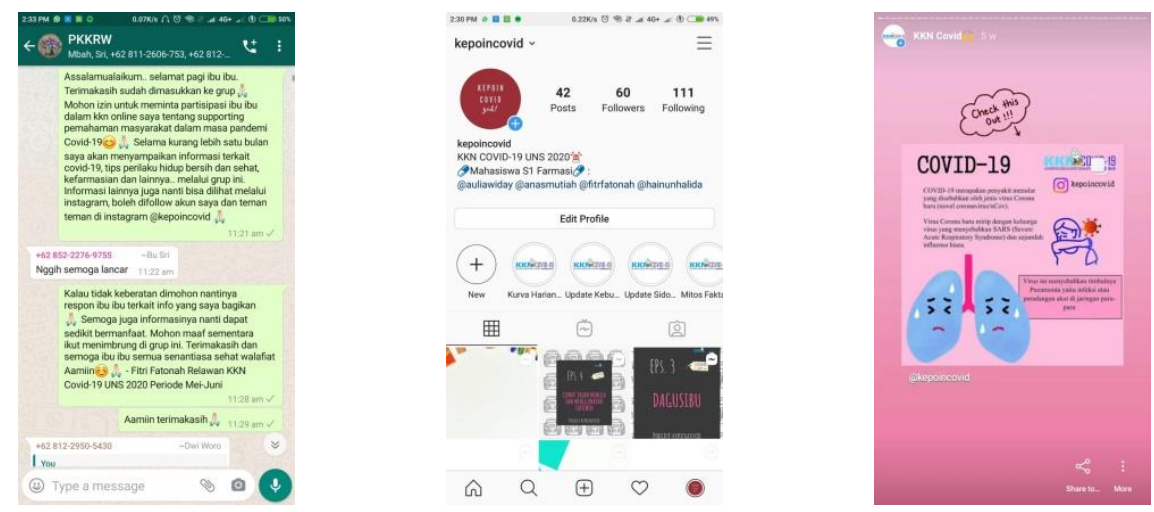

Gambar 1. WAG PKK RW 01, Instagram @kepoincovid, dan Instagram pribadi sebagai media pemberian edukasi

Adapun program-program dan materi yang dibagikan adalah sebagai berikut. Persiapan dan pengumpulan materi edukasi dilakukan sebelumnya agar dapat memberikan edukasi yang faktual dan informasinya berdasarkan sumber yang terpercaya.

Tabel 1. Program dan Materi Edukasi

Program

Edukasi fakta

seputar Covid-19

dan seputar

penggunaan obat

\section{Materi}

Definisi, gejala, cara penularan Covid-19; Perbedaan status

pasien Covid-19; Cara pencegahan penyebaran Covid-19; Physical distancing; Seputar penggunaan masker; New

Normal; Tips belanja offline maupun online di era New Normal;

Kenali Bahan Berbahaya pada Sediaan Farmasi Kosmetika; 
Tips Pencegahan Paparan Covid-19 di Tempat Kerja; Tips Mencegah Penularan Covid-19 di Kendaraan Umum; Tips Merawat Diri dan Mengelola Stress Akibat Covid-19; Orang yang Lebih Berisiko Terkena Covid-19; Cegah Virusnya, Dukung Orangnya; Buku Saku Penggolongan Obat; Buku Saku Penggunaan Obat; Cara Penggunaan Handsanitizer; Tips Aman Mendapatkan Obat Saat Pandemi; dan Dexamethasone di Era Covid-19.

Video edukasi Lagu DAGUSIBU, Tips membuat salad buah sehat, Animasi DAGUSIBU, Tips membuat kunyit asam segar, dan Langkah cuci tangan dengan sabun dan air mengalir.

Podcast

Teaser, Episode 1: Kebiasaan Baru Saat New Normal, Episode 2: Tips Menjaga Daya Tahan Tubuh di Era New Normal, Episode 3: DAGUSIBU, dan Episode 4: Cermat Dalam Memilih dan Menggunakan Suplemen.

Poster dan lealeat Poster yang ditempelkan di lingkungan sekitar yaitu Lawan Covid dengan \#DIRUMAHAJA, Lawan Covid dengan Etika Batuk dan Cara Menggunakan Masker yang benar, Lawan Covid dengan Jaga Jarak Biar Sehat, dan Lawan Covid dengan CANGGUNG: Cuci Tangan dengan Sabun dan Air Mengalir.

Sosialisasi door to door menggunakan leafleat dengan materi Langkah Cuci Cuci Tangan dengan Sabun dan Air Mengalir dan Tanya Obat Tanya 50

Info kasus Covid- Secara rutin 2 atau 3 hari sekali menginformasikan update 19 Kebumen dan pertambahan harian kasus Covid-19 di Kabupaten Kebumen Nasional dan Nasional. 


\subsection{Hasil Kuisioner Evaluasi Grup WAG PKK RW 01}

Adapun program-program dan materi yang dibagikan adalah sebagai berikut. Persiapan dan pengumpulan materi edukasi dilakukan sebelumnya agar dapat memberikan edukasi yang faktual dan informasinya berdasarkan sumber yang terpercaya.

Kuisioner Evaluasi Grup WAG PKK RW 01 diadakan untuk mengukur pemahaman anggota WAG selama diadakan KKN mengenai seputar Covid-19, penerapan PHBS, dan DAGUSIBU (Program 1 dan 2) melalui media WAG. Pengisian kuisioner ini diisi oleh 13 anggota WAG PKK RW 01. Berdasarkan hasil kuisioner juga anggota WAG PKK RW 01 dengan senang hati sudah melakukan Penerapan Hidup Bersih dan Sehat (PHBS).

Tabel 2. Hasil Evaluasi Melalui Kuisioner

\section{Fakta Seputar Covid-19}

1. Bagaimana informasi fakta seputar Covid-19 yang disampaikan?

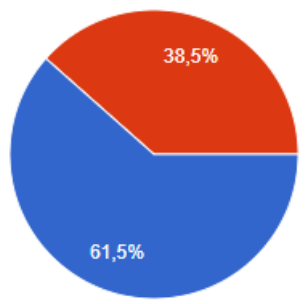

Sangat mudah dipahami

Bisa dipahami

Kurang bisa dipaham

Susah dipahami

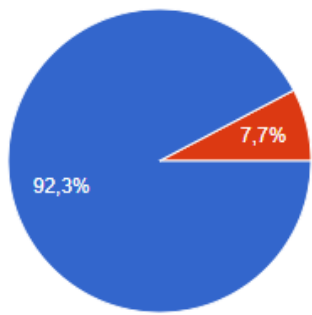

Sangat bermanfaat

Cukup bermanfaat

Kurang bermanfaat

Tidak bermanfaat Covid-19 tersebut?

Penerapan PHBS serta tips kesehatan dalam rangka menghadapi Covid-19

1. Bagaimana informasi PHBS serta tips kesehatan dalam rangka menghadapi Covid-19 yang disampaikan?

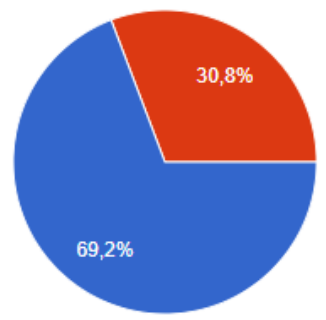


2. Bagaimana tingkat kemanfaatan dari informasi PHBS serta tips kesehatan dalam rangka menghadapi Covid-19 tersebut?

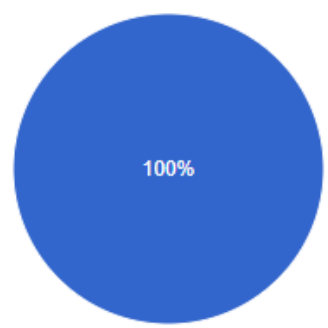

3. Apakah sudah menerapkan PHBS serta tips kesehatan dalam rangka menghadapi Covid-19? (Memakai masker ketika bepergian, rajin cuci tangan dII)

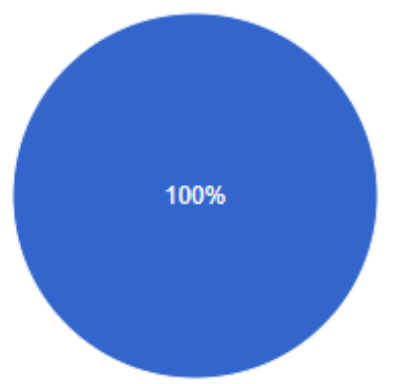

\section{DAGUSIBU (Dapatkan, Gunakan, Simpan, Buang) Obat dengan Benar}

1. Bagaimana informasi DAGUSIBU yang disampaikan?

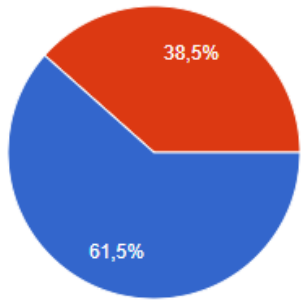

Sangat mudah dipaham Bisa dipahami

Kurang bisa dipahami Susah dipahami

2. Bagaimana tingkat kemanfaatan dari informasi DAGUSIBU tersebut?

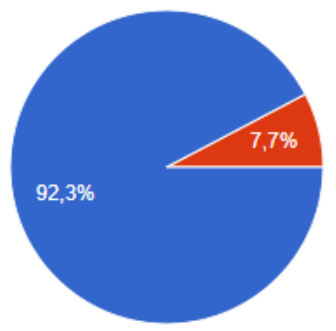

\subsection{Hasil Quiz Mitos dan Fakta Seputar Covid-19}

Quiz Mitos dan Fakta diadakan di Instagram untuk mengukur pemahaman seputar Covid19 (Program 1, 2, dan 3). Terdapat tiga puluh soal dengan pilihan jawaban mitos atau fakta yang dibagikan bertahap lima soal per hari (terdapat enam sesi). Soal dibagikan melalui fitur story pada akun instagram empat orang admin akun kepoincovid agar lebih banyak peserta yang berpartisipasi dan penjelasannya dibagikan di akun kepoincovid. Reward berupa gopay atau ovo senilai Rp25.000 diberikan kepada masing-masing delapan peserta quiz dengan skor tertinggi 
untuk menarik minat mengikuti quiz dimana anggaran untuk masing-masing admin adalah reward untuk dua orang pemenang. Soal dan penjelasan quiz menggunakan referensi dari Mitos Covid19 Dokter Awam update 9 Mei 2020.

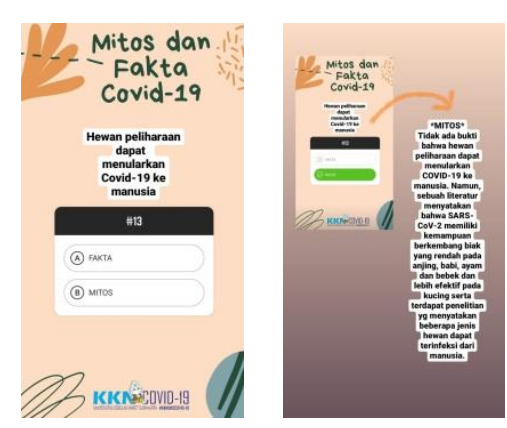

\section{Gambar 2. Contoh soal dan penjelasan quiz}

Quiz diikuti oleh total 346 peserta yang setidaknya pernah mengikuti salah satu sesi dari enam sesi quiz. Pemenang secara berurutan yaitu @choirulisaptr 26 skor benar, @whyatika 25 skorbenar, @sofiaaulia_dan @viraalrs 24 skor benar, @lailinakhwa 22 skor benar, @putriiwdy dan @meylianaadhitya 21 skor benar, @rahma_amaliaw 20 skor benar. Bagi peserta quiz yang jawabannya salah dapat mengecek penjelasannya sehingga dapat meluruskan pemahamannya mengenai mitos atau fakta seputar Covid-19.

\section{PENUTUP}

Berdasarkan hasil dan pembahasan yang sudah disampaikan diketahui bahwa anggota WAG yang mengisi kuisioner dan para peserta quiz mitos dan fakta memiliki pengetahuan dan kemampuan untuk mengantisipasi penyebaran virus serta lebih waspada dan tenang dalam menghadapi pandemi yang sedang berlangsung. Edukasi dengan cara dan media apapun adalah hal yang penting untuk membentuk individu dan mengajarkan mereka tentang bagaimana bertindak dan berperilaku. Dalam situasi pandemi ini strategi pemanfaatan media sosial untuk mengedukasi perilaku masyarakat dalam lingkungan sekitar bermanfaat dalam penanggulangan Covid-19.

Masyarakat terus dihimbau untuk meningkatkan perilaku hidup bersih dan sehat dalam upaya pencegahan penyebaran Covid-19 untuk menurunkan angka penyebaran Covid-19. Melalui media sosial, masyarakat dengan mudah berbagi informasi terkait Covid-19. Ibu-ibu PKK 
RW 01 khusunya dapat bertindak sebagai guru yang mampu mengedukasi anggota keluarga masing-masing maupun masyarakat.

\section{DAFTAR PUSTAKA}

Allington, D., Duffy, B., Wessely, S., Dhavan, N., \& Rubin, J. (2020). Health-protective behaviour, social media usage and conspiracy belief during the COVID-19 public health emergency. Psychological medicine, 1-7.

Giota, K. G., \& Kleftaras, G. (2014). Social media and counseling: Opportunities, risks and ethical considerations. International Journal of Psychological and Behavioral Sciences, 8(8), 23862388.

Karo, Marni Br. (2020). "Perilaku Hidup Bersih dan Sehat (PHBS) Strategi Pencegahan Penyebaran Virus Covid-19." Prosiding Seminar Nasional Hardiknas. Vol 1, hal. 1-4.

Kaya, Mehmet, Şuayip Birinci, Jalal Kawash, \& Reda Alhajj. (2020). "Putting Social Media and Networking Data in Practice for Education, Planning, Prediction and Recommendation". Lecture Notes in Social Networks dalam https://www.springer.com/gp/book 19783030336974 diakses 12 Juli 2020.

Kurniawati, Kiki Riska Ayu, Farah Heniati Santosa, dan Samsul Bahri. (2020). "Sosialisasi Hidup Sehat di Tengah Wabah Virus Corona". JPMB: Jurnal Pemberdayaan Masyarakat Berkarakter. Vol 3, No 1, hal. 58-65.

Limaye, R. J., Sauer, M., Ali, J., Bernstein, J., Wahl, B., Barnhill, A., \& Labrique, A. (2020). Building trust while influencing online COVID-19 content in the social media world. The Lancet Digital Health, 2(6), e277-e278.

Pennycook, G., McPhetres, J., Zhang, Y., Lu, J. G., \& Rand, D. G. (2020). Fighting COVID-19 misinformation on social media: Experimental evidence for a scalable accuracy-nudge intervention. Psychological science, 31(7), 770-780.

Sampurno, Muchammad Bayu Tejo, Tri Cahyo Kusumandyoko, \& Muh Ariffudin Islam. (2020). "Budaya Media Sosial, Edukasi Masyarakat dan Pandemi COVID-19". SALAM; Jurnal Sosial \& Budaya Syar-i. Vol 7, No 6, hal. 529-542.

Sulaeman \& Supriadi. (2020). "Peningkatan Pengetahuan Masyarakat Desa Jelantik Dalam Menghadapi Pandemi Corona Virus Diseases-19 (Covid-19)". Jurnal Pengabdian UNDIKMA. Vol 1, No 1, hal.12-17.

Thielst, CB . Social media: ubiquitous community and patient engagement. Front Health Serv Manage 2011; 28(2): 3-14.

World Health Organization, "Coronavirus" dalam https://www.who.int/healthtopics/coronavirus\#tab=tab 1 diakses 12 Juli 2020. 